UDC 681.51

\title{
MODERNIZATION OF LUENBERGER OBSERVER FOR CONTROL SYSTEM OF HERMETIC COMPRESSOR ELECTRIC DRIVE
}

Bukaros A. Y. - PhD, Associate Professor of the Department of Electromechanics and Mechatronics, Odessa National Academy of Food Technologies, Odessa, Ukraine.

Onyshchenko O. A. - Dr. Sc., Professor of the Department of Fleet Technical Operation, National University "Odessa Maritime Academy", Odessa, Ukraine.

Montik P. N. - PhD, Professor, Head of the Department of Electromechanics and Mechatronics, Odessa National Academy of Food Technologies, Odessa, Ukraine.

Malyshev V. L. - Post-graduate student of the Department of Automation of Technological Processes and Robotic Systems, Odessa National Academy of Food Technologies, Odessa, Ukraine.

Bukaros V. N. - Post-graduate student of the Department of Fleet Technical Operation, National University "Odessa Maritime Academy". Odessa, Ukraine.

\section{ABSTRACT}

Context. The analysis of existing systems of sensorless control of hermetic compressor electric drives is carried out. The main requirements for control systems of automated electric drives of small refrigerating units' hermetic compressors are determined. The topology of the adaptive Luenberger observer, which allows real-time estimation of the current value of the rotational speed and load torque on the shaft of the hermetic compressor electric motor, is proposed.

Objective. The object of the study is the coordinates observer as a part of control system of the hermetic compressor electric drive. The purpose of the work is to develop a mathematical model of the coordinates observer as a part of control system of the hermetic compressor electric drive.

Method. Based on the linearized model of a three-phase induction motor, the Luenberger observer is synthesized by the modal method with the distribution of the roots of the characteristic polynomial according to the standard linear Bessel form.

Results. The characteristic polynomial of the observer is obtained and the coefficients of the Luenberger matrix and the mean geometric root of the characteristic polynomial are calculated. To ensure the necessary accuracy the structure of the observer on the basis of the complete mathematical model of a three-phase induction motor executed in the fixed coordinate system is proposed. In the Matlab/Simulink simulation environment an imitation model of the Luenberger observer, which includes a complete mathematical model of the hermetic compressor electric motor in the fixed coordinate system, is constructed. By means of simulation modeling the work of the projected Luenberger observer is studied using the example of the modernized three-phase induction motor of the domestic refrigerator's hermetic compressor.

Conclusions. The efficiency of the proposed method for identifying the rotational speed and the load torque of the compressor motor by the adaptive observer based on the calculation of the motor's electromagnetic moment from the measured data of the phase voltage and current sensors is confirmed. The error of the researching observer does not exceed $0.5 \%$ at the rotation speed and $10 \%$ at the load torque. The obtained structure of the adaptive Luenberger observer makes it possible to build closed control systems for the electric drive of a small refrigerating unit's hermetic compressor.

KEYWORDS: Luenberger's observer, electric drive, control system, hermetic compressor, refrigeration unit.

\begin{abstract}
ABBREVIATIONS
AED is an automated electric drive; $\mathrm{FC}$ is a frequency converter; SRU is a small refrigeration unit; TIM is a three-phase induction motor.
\end{abstract}

\section{NOMENCLATURE}

A is an own matrix of TIM as a control object;

$\mathbf{B}$ is a control matrix of TIM;

C is an output matrix of TIM;

$\mathbf{X}$ is a state coordinates vector of TIM;

$\mathbf{M}$ is a perturbation matrix of TIM;

$\mathbf{Y}$ is a vector of output (measured) variables of TIM;

$\hat{\mathbf{Y}}$ is an estimated value of the vector $\mathbf{Y}$;

$\mathbf{H}$ is an observability matrix;

$\mathbf{L}$ is a Luenberger matrix;
$\mathbf{E}$ is a single matrix;

$L_{1}, L_{2}$ are Luenberger matrix elements;

$M$ is an electromagnetic torque;

$\hat{M}$ is an estimated value of the electromagnetic torque;

$M_{c}$ is a load torque;

$\hat{M}_{c}$ is an estimated value of the load torque;

$\Omega$ is a rotor speed;

$\hat{\Omega}$ is an estimated value of the rotor speed;

$T_{2}$ is a rotor time constant;

$z_{p}$ is a number of pair of poles;

$h_{i}$ is a stiffness of TIM mechanical characteristic;

$\omega_{1}$ is an electrical network angular frequency;

$\omega_{1 \mathrm{H}}$ is a nominal value of the electrical network angular frequency;

(C) Bukaros A. Y., Onyshchenko O. A., Montik P. N., Malyshev V. L., Bukaros V. N., 2019

DOI 10.15588/1607-3274-2019-1-21 
$\omega_{2}$ is a angular current frequency of the rotor;

$J$ is an inertia moment;

$u$ is a control action;

$f$ is a perturbation;

$A_{1}$ is a coefficient of shape, according to the accepted

standard Bessel linear form;

$\Omega^{\prime}$ is a mean geometric root;

$D(p)$ is characteristic polynomial;

$N(p)$ is an normalized polynomial;

$p$ is a polynomial variable;

$f_{1 H}$ is a nominal frequency of the modernized TIM.

\section{INTRODUCTION}

Small refrigeration units are now widely used in the food industry, trade and households for food storage. Basically, these are compressor refrigeration units equipped with single-cylinder reciprocating, indirect, hermetic compressors with electric drive. Since the world output of SRU is measured in hundreds of millions units, the possibility of even a small improvement (on a fraction of one percent) in the energy characteristics or a reduction in the material consumption of the compressor electric drive can lead to significant savings.

These capabilities can be obtained by automated control of the compressor motor speed [1-3], and, therefore, the cooling capacity of the SRU. This technical solution allows reducing operating and manufacturing costs for a controlled electric drive of the compressor. However, manufacturers of refrigeration equipment face the complex task of developing an electric drive control system in the absence of the technical possibility of installing a speed sensor in a hermetic compressor. Another problem is the significant influence on the control system of the disturbing effect (the load torque on the shaft of the compressor motor), which has a pronounced pulsating and variable character.

An effective solution to these problems is possible by using adaptive state observers.

\section{PROBLEM STATEMENT}

When state observers are used, a TIM mathematical model is introduced into the control system, which estimates the current value of the rotor speed. Usually equations describing only electromagnetic processes in the TIM are used for this purpose, supposing that in most applications of the frequency drive the value of the total moment of inertia of the electric motor and the associated mechanism is unknown and often difficult to determine. In this case, the measured coordinates of the electric drive state are the phase currents of the TIM stator, and the restored coordinate is the rotor speed, which is determined by the proportional-integral adaptation algorithm. This approach allows easily determining the value of the rotor speed, while the problem of effective identification of the compressor load torque remains unresolved.

The aim of the research is to develop the mathematical model of the coordinates observer for the automated electric drive "frequency converter - three-phase induction mo- tor" of a hermetic compressor that allows real-time estimation of the rotor speed and the load torque on the shaft.

To achieve this aim, it is necessary to solve a number of particular tasks:

- to develop the structure of the coordinates observer on the basis of existing Luenberger observers;

- to synthesize the model of the coordinates observer allowing to estimate the engine rotation frequency and the load torque on the shaft in real time;

- to conduct a research of the accuracy of the received coordinates observer by means of simulation.

\section{REVIEW OF THE LITERATURE}

A number of publications have been devoted to the selection, design and development of AED for a hermetic compressor of SRU [4-8]. The range of the technical solutions under consideration is quite extensive, but all authors state the idea of the prospect of using the electric drive "frequency converter - three-phase induction motor". The choice of a control system for the AED of SRU hermetic compressors in [4-8] is suggested to be guided by the following considerations:

- the AED control system should have the simplest circuit design;

- the AED control system must provide the required range of performance control of the compressor.

- the AED control system should provide an acceptable level of ripple of the compressor engine speed.

As shown in [9], the load torque on the shaft of the piston compressor engine has a pronounced pulsating character, and its maximum value for one revolution of the motor shaft can reach triple excess of the nominal value. Such pulsations of the load torque lead to pulsations of the rotational speed of the crankshaft on which the rotor of the motor is mounted [9]. For an induction motor mounted on the compressor shaft, ripples not exceeding $1.25 \%$ are regulated at the rated speed of rotation. This value is due to the allowable thermal load of the motor windings.

Since most of the thermal power released in the engine stator is due to magnetic losses proportional to the square of the frequency of the supply voltage, in frequency control, the magnitude of the ripple of the engine speed can be increased inversely proportional to the square of the speed control range.

It should also be taken into account that for the commercially available single-phase motors used in the SRU compressors, the total mass of the stator and rotor steel ranges from 3 to $5.5 \mathrm{~kg}$ [10]. At the same time, TIM of similar power has a much smaller moment of inertia: the total mass of stator and rotor steel is $1.35 \ldots 2.1 \mathrm{~kg}$.

Taking into account the stated requirements to the magnitude of the rotational speed ripple, the use of open control systems for the TIM of a hermetic compressor in the operation of FC in the voltage source mode is inexpedient due to the low rigidity of the mechanical characteristics [11]. The operation of the inverter in the current source mode allows obtaining more rigid mechanical characteristics of the electric drive with 
preservation of the critical moment constant, thus the open control system will be practically inoperative [11] The maximum rigidity of mechanical characteristics during FC operation in the current source mode can be obtained in a closed two-loop system of subordinate coordinate control [11] with current and speed controllers.

In order to construct a closed-loop control system for the electric drive of the FC-TIM hermetic compressor, it is necessary to locate the current value of the TIM speed that could be easily identified. The existing methods for determining the rotation speed of the TIM require:

- installation of a speed sensor in a hermetic compressor, which is fraught with great technical difficulties;

- or real-time implementation of complex coordinate transformations and / or differentiation operations in case of sensorless determination of the rotational speed, which considerably complicates and increases the cost of the electric drive as a whole.

Since the SRU operates with a variable thermal load [1], and taking into account the requirements for the magnitude of the rotational speed ripple, it is necessary to ensure the robustness of the FC-TIM electric drive control system of the hermetic compressor. To do this, it is required to determine in real time the magnitude of the perturbing effect - the load torque on the compressor shaft. The magnitude of the load torque is almost impossible to measure directly, and its definition from the equations of the TIM mathematical model requires the derivative calculation of the rotational speed [11]. Therefore, an additional condition to the control system, except the relatively simple identification of the TIM rotation frequency, will be to provide real-time determination of the magnitude of the load torque on the compressor shaft without using differentiation operations.

In practice, in three-phase AED special algorithms for identifying the state coordinates from the data of only measured stator currents and voltages have been most widely used [12]. In particular, there are model reference adaptive systems [13], state observers [12, 14, 15], Kalman filters $[16,17]$, etc. An analysis of the works [12, 17] allows concluding that the most effective and easy to implement algorithms constructed on the basis of the adaptive full order Luenberger observers. Therefore, further we consider the construction of the FC-TIM electric drive control system by the Luenberger observers $[12,14]$.

\section{MATERIALS AND METHODS}

The object of the research is the FC-TIM electric drive, as a single mechatronic system for a specific application in hermetic compressors of SRU. Therefore, the moment of inertia of the TIM and the rotating parts of the compressor crank mechanism [9] can be determined even at the design stage of such electric drive. Therefore, when the coordinate observer is constructing, it becomes possible to use the equations of both the electromagnetic and the mechanical parts of the TIM mathematical model (Fig. 1).

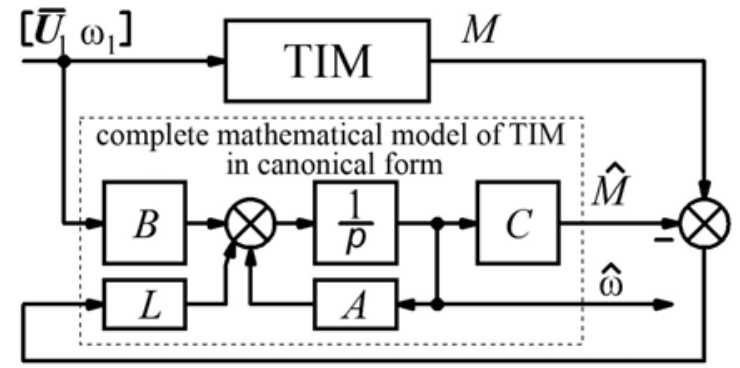

Figure 1 - Luenberger observer for the electric drive of a hermetic compressor

In this case, the electromagnetic torque of the TIM, calculated from the values of the phase voltages and currents [11], can be used as the measured coordinate. Thus, the simulation model of the observer being developed will consist with blocks of the TIM simulation model with the addition of feedbacks realized by the matrix $\mathbf{L}$.

When the coefficients of the matrix $\mathbf{L}$ is calculating, the use of the equations of the TIM mathematical model writing in the canonical form [11] for the torque and rotation frequency of the TIM, is directly difficult, because the electromagnetic torque $\mathrm{M}$ is determined by the products of the projections of the stator current and flux vectors. However, this is not necessary, in view of the fact that the coefficients of the matrix $\mathbf{L}$ are determined on the basis of general recommendations [12,15] and affect only the state coordinates identification speed by the observer. Therefore, it is permissible to use the linearized TIM model [11].

The synthesis of the Luenberger observer and the determination of its parameters are carried out by a modal method with the distribution of the roots of the characteristic polynomial according to the standard linear Bessel form [15]. The starting point of the calculation is the canonical form of the differential equations of the linearized mathematical model of the TIM, which looks like this:

$$
\begin{gathered}
\frac{d}{d t} M=-\frac{1}{T_{2}} M-\frac{z_{p} \cdot h_{i}}{T_{2}} \Omega+\frac{h_{i}}{T_{2}} \omega_{1} \\
\frac{d}{d t} \Omega=\frac{1}{J} M-\frac{1}{J} M_{\mathrm{c}}
\end{gathered},
$$

$$
\text { where }\left[\begin{array}{c}
M \\
\Omega
\end{array}\right]=\mathbf{X} ; \omega_{1}=u ; M_{\mathrm{c}}=f ;\left[\begin{array}{cc}
-\frac{1}{T_{2}} & -\frac{z_{p} \cdot h_{i}}{T_{2}} \\
\frac{1}{J} & 0
\end{array}\right]=\mathbf{A} \text {; }
$$

$$
\left[\begin{array}{c}
\frac{h_{i}}{T_{2}} \\
0
\end{array}\right]=\mathbf{B} ;\left[\begin{array}{l}
0 \\
\frac{1}{J}
\end{array}\right]=\mathbf{M} \text {. }
$$

Thus, the system of equations (1) in the vector-matrix form completely corresponds to the canonical form of the TIM representation, as the control object: $\dot{\mathbf{X}}=\mathbf{A X}+\mathbf{B} u+\mathbf{M} f$. 
It is assumed that in the control system a direct measurement of the TIM electromagnetic torque $\mathrm{M}$ is made, according to Fig. 1. Then the output matrix $\mathbf{C}=\left[\begin{array}{ll}1 & 0\end{array}\right]$, and the vector of output (measured) variables:

$$
\mathbf{Y}=\mathbf{C X}=\left[\begin{array}{ll}
1 & 0
\end{array}\right] \cdot\left[\begin{array}{l}
M \\
\Omega
\end{array}\right]=M .
$$

An observer for the state coordinate vector estimating is constructed on the basis of the mathematical model of the TIM by adding it to the "stabilizing additive" $\mathbf{L}(\mathbf{Y}-\hat{\mathbf{Y}})[12,14]$. Assuming the perturbation is uncontrollable, and taking into account expressions (1) and (2), the linerized mathematical model of the complete Luenberger observer for the TIM will take the form:

$$
\begin{gathered}
\frac{d}{d t} \hat{M}=-\frac{1}{T_{2}} \hat{M}-\frac{z_{p} \cdot h_{i}}{T_{2}} \hat{\Omega}+\frac{h_{i}}{T_{2}} \omega_{1}+L_{1}(M-\hat{M}) . \\
\frac{d}{d t} \hat{\Omega}=\frac{1}{J} \hat{M}+L_{2}(M-\hat{M})
\end{gathered}
$$

The observer's synthesis begins with the observability condition checking of the TIM as a control object expressed by the requirement of the equality of the observability matrix $\mathrm{H}$ rank to control object order [15] According to equations (1), the order of the linearized TIM model is two. The observability matrix for the accepted control object:

$$
\mathbf{H}=\left[\mathbf{C}^{T} \vdots \mathbf{A}^{T} \mathbf{C}^{T}\right]=\left[\begin{array}{cc}
1 & -\frac{1}{T_{2}} \\
0 & -\frac{z_{p} \cdot h_{i}}{T_{2}}
\end{array}\right] .
$$

The rank of the resulting observability matrix $\mathbf{H}$ is two, which satisfies the condition of the observability. The elements of the matrix $\mathbf{L}$ are determined by equating the characteristic polynomial of the observer $D(p)$ to the normalized polynomial $N(p)$ [15]:

$$
|p \mathbf{E}-\mathbf{A}+\mathbf{L C}|=p^{2}+A_{1} \Omega^{\prime} p+\left(\Omega^{\prime}\right)^{2},
$$

where $\Omega^{\prime}$ is chosen from the condition of ensuring the required performance of observer response speed; $A_{1}$ equals to 1.73 according to the accepted standard Bessel linear form.

Characteristic polynomial of observer is:

$$
\begin{gathered}
D(p)=|p \mathbf{E}-\mathbf{A}+\mathbf{L C}|= \\
=p^{2}+\left(\frac{1}{T_{2}}+L_{1}\right) \cdot p-\frac{z_{p} \cdot h_{i} \cdot\left(J \cdot L_{2}-1\right)}{T_{2} \cdot J} .
\end{gathered}
$$

Equating the corresponding coefficients $D(p)$ and $N(p)$ we obtain:

$$
L_{1}=A_{1} \cdot \Omega^{\prime}-\frac{1}{T_{2}} \quad L_{2}=\frac{1-\left(\Omega^{\prime}\right)^{2} \cdot T_{2} \cdot J}{z_{p} \cdot h_{i} \cdot J} .
$$

As noted earlier, the value of $\Omega^{\prime}$ in the general case is determined by the required observer response speed, which in $5 \quad \ldots 10$ times exceeds of the processes speed proceeding in the TIM. Since the velocity of all dynamic processes occurring in the TIM is determined in the first turn by the voltage nominal frequency of the supplied to the motor, it is recommended to take the value of the geometric root equal to

$$
\Omega^{\prime}=(5 \ldots 10) \cdot \omega_{1 \mathrm{H}} .
$$

To ensure the greatest accuracy of the observer, it is desirable to implement it on the basis of the complete mathematical model of the TIM, executed in a fixed coordinate system [11]. For this equation, the observer (3) is expediently converted to the form:

$$
\begin{gathered}
T_{2} \frac{d}{d t} \hat{M}+\hat{M}=h_{i} \cdot\left[\omega_{1}-z_{p} \cdot \hat{\Omega}+\frac{T_{2} \cdot L_{1}}{h_{i}} \cdot(M-\hat{M})\right] . \\
J \frac{d}{d t} \hat{\Omega}=\hat{M}+J \cdot L_{2}(M-\hat{M})
\end{gathered}
$$

The transformed equations correspond to the structural scheme shown in Fig. 2. Analysis of equations (9) and diagrams in Fig. 2 allows concluding that the "stabilizing additive" $J \cdot L_{2}(M-\hat{M})$ is actually the estimated value of the TIM load torque $\hat{M}_{c}$ and in the scheme is given to an adder calculating the dynamic moment of the entire electromechanical system of the TIM compressor. In turn, the "stabilizing additive" $\frac{T_{2} \cdot L_{1}}{h_{i}} \cdot(M-\hat{M})$ is given to an adder calculating the frequency of the rotor $\omega_{2}$.

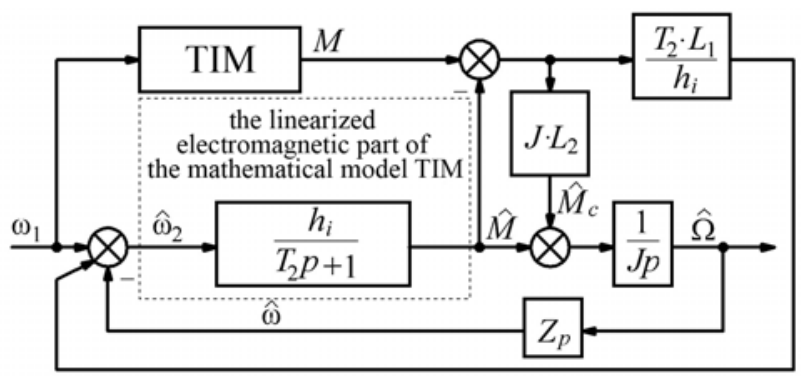

Figure 2 - Structural diagram of the linearized Luenberger observer

The obtained observer structure allows on its basis to construct in the Matlab / Simulink environment a simulation model of the Luenberger observer, which includes the complete mathematical model of the TIM in a fixed coordinate system (Fig. 3). 


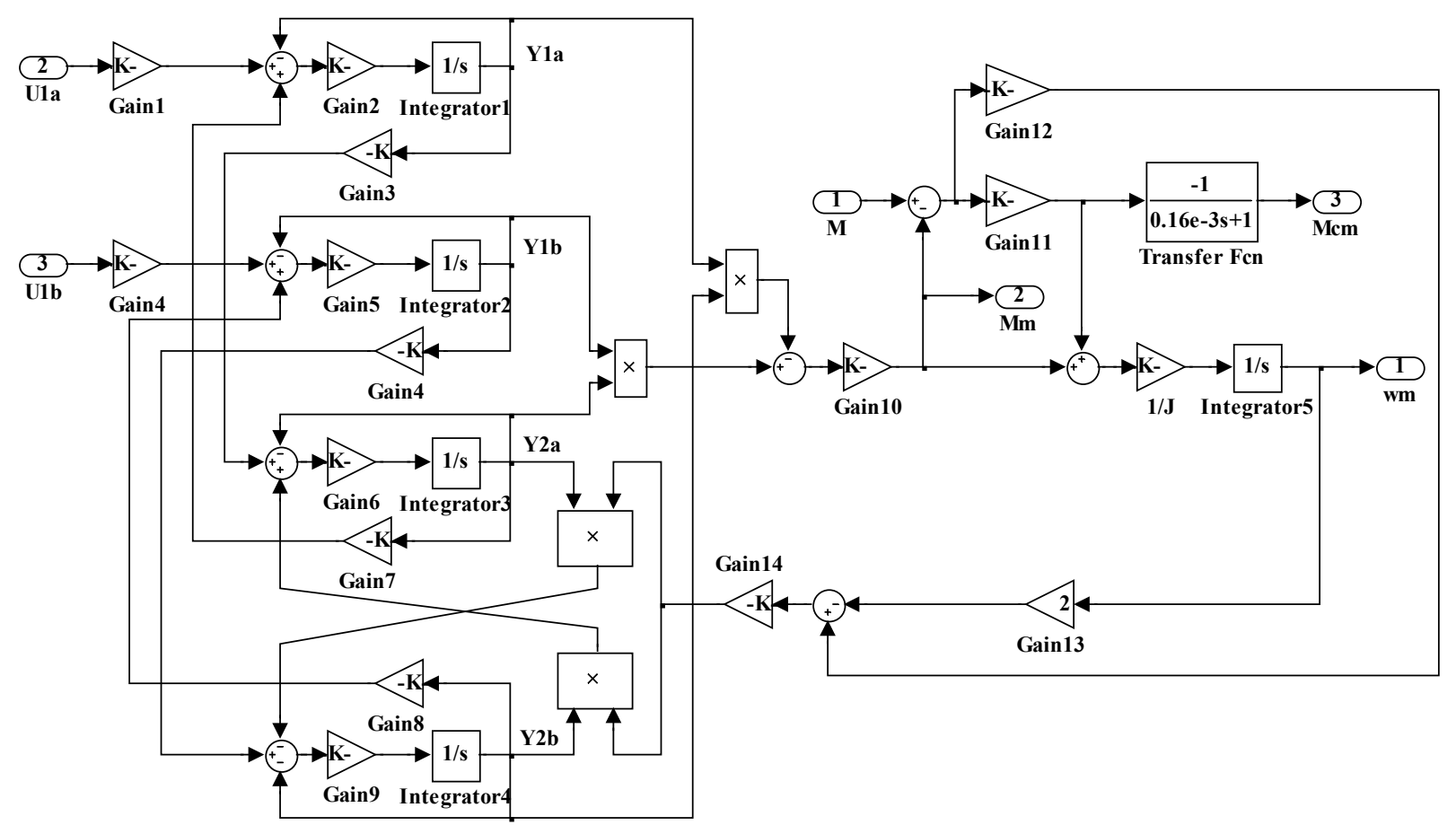

Figure 3 - Simulation model of the Luenberger observer

In the presented model, the coefficients $T_{2} \cdot L_{1} / h_{i}$ and $J \cdot L_{2}$ are implemented by the Gain 11 and Gain12 amplifiers, respectively, the calculated TIM electromagnetic moment value is fed from the input port 1 and its estimate from the output of the Gain10 amplifier. At the output of the blocks Integrator 1 ... Integrator4, the estimated values of the stator and rotor magnetic fluxes $\Psi_{1 \alpha}, \Psi_{1 \beta}, \Psi_{2 \alpha}, \Psi_{2 \beta}$ in the fixed coordinate system are calculated from the equations in [11], taking into account (10). At the output of the Integrator5 unit an estimate of the current value of the TIM rotational speed value is generated, which is then used for rotational feedback.

\section{EXPERIMENTS}

Researches of the obtained model of the Luenberger observer were carried out using the data of the modernized TIM taken from [18]. Since the nominal frequency of the modernized TIM is $f_{1 \mathrm{H}}=100 \mathrm{~Hz}$, the value of the geometric root that characterizes the speed of the Luenberger observer is taken $\Omega^{\prime}=6280 \mathrm{~s}^{-1}$. This value corresponds to the values of the coefficients of the Luenberger matrix: $L_{1}=15958$ and $L_{2}=-8110$.

\section{RESULTS}

As a result of simulations of the Luenberger observer in conjunction with the TIM of the hermetic compressor of the SRU at the nominal frequency signal and the nominal compressor load, whose mean value is $0.3 \mathrm{~N} \cdot \mathrm{m}$, graphs have been obtained for changing the rotational speed $\hat{\Omega}$ and the load torque $\hat{M}_{\mathrm{c}}$ of the researched TIM and as well as their assessments and at the output of the observer (Fig. 4).
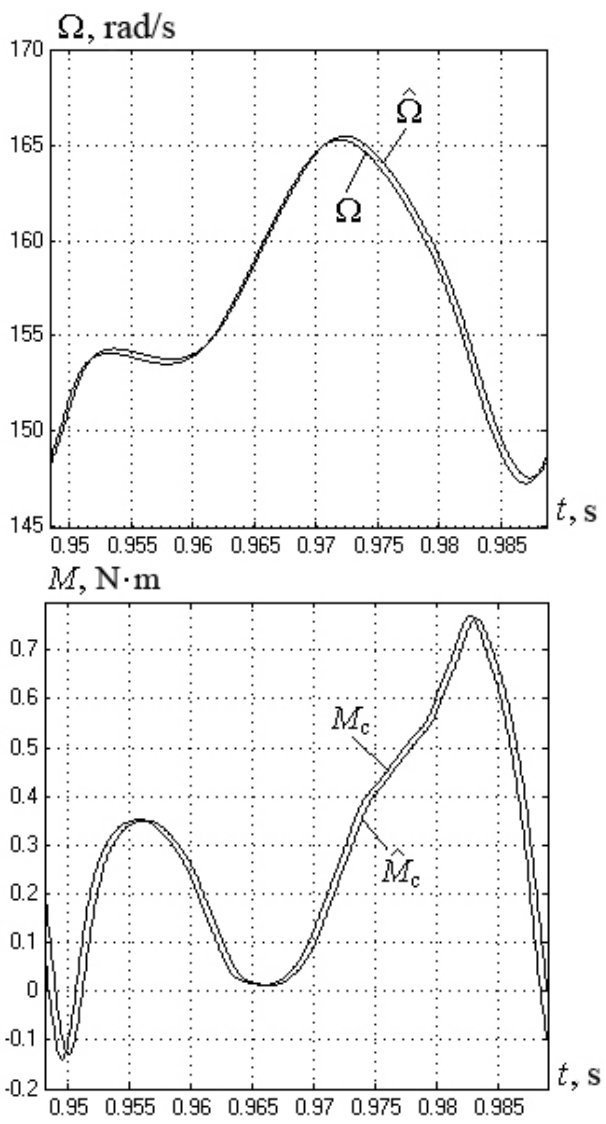

Figure 4 - TIM state coordinates changing and their estimation 


\section{DISCUSSION}

From fig. 4 it can be seen that the estimated coordinates of the compressor electric drive state are sufficiently close to their real values, and the observer's error does not exceed $0.5 \%$ at the rotational speed and $10 \%$ at the load torque. The increased value of the error of load torque estimating the investigated TIM in comparison with the estimate rotation speed is explained, on the one hand, by the presence of the second "stabilizing" addition $T_{2} \cdot L_{1} / h_{i} \cdot(M-\hat{M})$, and, $J \cdot L_{2}(M-\hat{M})$ on the other hand, by the installation of the filter (Fig. 3, block Transfer Fen) to exclude high-frequency components in estimate signal $M_{c}$.

\section{CONCLUSIONS}

The problem of real-time determination of the rotor speed and the load torque of the electric drive of a small refrigerating unit's hermetic compressor is solved using the designed Luenberger observer.

The scientific novelty of obtained results is that the method for identifying the TIM rotor speed and compressor load torque by the developed full-order Luenberger observer has been further developed. The observer's error does not exceed $0.5 \%$ of the rotational speed and $10 \%$ at the load torque.

The practical significance of obtained results is that the obtained structure of the Luenberger's observer allows to design closed by an observer control systems of automated electric drive of small refrigeration unit's hermetic compressor.

Prospects for further research are to improve the accuracy of the load torque estimation by improving of the proposed structure of the Luenberger observer on the basis of observers of a reduced order.

\section{ACKNOWLEDGMENTS}

The work was carried out at the department of Electromechanics and Mechatronics at Odessa National Academy of Food Technologies and the department of Fleet Technical Operation at National University "Odessa Maritime Academy" within the framework of collaborative scientific research conducted by the departments.

\section{REFERENCES}

1. Onishhenko O. A. Nauchnoe obosnovanie i razrabotka avtomatizirovannyh sistem upravlenija holodil'nokompressionnymi ustanovkami maloj proizvoditel'nosti : dis. ... d-ra tehn. nauk : 05.13.07 / Onishhenko Oleg Anatol'evich. Odessa, 2010, $345 \mathrm{p}$.

2. Saidur R., Mekhilef S., Ali M. B., Safari A., Mohammed H. A. Applications of variable speed drive (VSD) in electrical motors energy savings, Renewable and Sustainable Energy Reviews, 2012, Vol. 16, Issue 1, pp. 543-550. DOI: 10.1016/j.rser.2011.08.020.

3. Li Yu., Chomat M. Variable Frequency Drive Applications in HVAC Systems, New Applications of Electric Drives, IntechOpen, 2015. DOI: 10.5772/61782.
4. Vojteh V. A. Chastotnoe regulirovanie skorosti vrashhenija asinhronnih dvigatelej kompressorov bytovyh holodil'nikov, Tehnichna elektrodinamika. Temat. vip. "Problemi suchasnoï elektrotehniki”, 2004, No. 3, pp. 61-63.

5. Ledesma S., Belman-Flores J. M., Barroso-Maldonado J. M. Analysis and modeling of a variable speed reciprocating compressor using ANN, International Journal of Refrigeration, 2015, Vol. 59, pp. 190-197. DOI: 10.1016/j.ijrefrig.2015.08.009.

6. Grech N., Farrugia M. Experimental Investigation of Variable Speed Operation of Air Conditioning, In Proceedings of the 9th International Conference on Heat Transfer, Fluid Mechanics and Thermodynamics. Malta, 2012, pp. 16741682.

7. Marshall R. C. Optimization of Single-unit Compressed Air Systems, Energy Engineering, 2012, Vol. 109, pp. 10-35. DOI: 10.1080/01998595.2012.1043657.

8. Naveenkumar M., Munjal A., Srinivasan S., Prasad D. Design and implementation of a variable frequency drive for single-phase induction motor, IEEE International WIE Conference on Electrical and Computer Engineering (WIECONECE). Dhaka, 2015, pp. 239-242. DOI: 10.1109/wieconece.2015.7443907

9. Bukaros A. Ju., Bukaros V. N., Onishhenko O. A. Modelirovanie momenta soprotivlenija odnoporshnevogo kompressora sudovoj holodil'noj ustanovki, Tehnologicheskij audit $i$ rezervy proizvodstva, 2015, No. 4 (1), pp. 46-51.

10. Boldea I., Nasar S. A. The Induction Machine Handbook. Electric Power Engineering Series. CRC Press, 2010, 968 p.

11. Krause P. C., Wasynczuk O., Sudhoff S. D. Analysis of electric machinery and drive systems, 3rd ed. New York, Wiley-IEEE, 2013, $680 \mathrm{p}$.

12. Mustapha M., Sbita L., Mouna B. H., Habib K. MRAS and Luenberger Observer Based Sensorless Indirect Vector Control of Induction Motors, Asian Journal of Information Technology, 2008, Vol. 7, pp. 232-239.

13. Khan M. R., Iqbal A. Model reference adaptive system with simple sensorless flux observer for induction motor drive, IEEE International Conference on Power Electronics, Drives and Energy Systems (PEDES). Bengaluru, 2012, pp. 1-6. DOI: 10.1109/PEDES.2012.6484442.

14. Kubota H., Matsuse K., Nakano T. DSP-based speed adaptive flux observer of induction motor, IEEE transactions on industry applications, 1993, Vol. 29, pp. 344-348.

15. Corriou J.-P. Process control: Theory and applications: Second edition. Springer International Publishing, 2018, 860 p. DOI: 10.1007/978-3-319-61143-3.

16. Galaguz T. A., Abramovych O. O., Komnac'ka M. M. Porivnjannja rezul'tativ syntezu robastnyh system upravlinnja $\mathrm{z}$ vykorystannjam sposterigacha Kalmana ta sposterigacha Ljuenbergera, Systemy upravlinnja, navigacii' ta zv'jazku, 2010, No. 2(14), pp. 75-82.

17. Ning C. Kalman filtering speed estimation of vector control for induction motor drive, Conference: IEEE Powercon 2016. Wollongong, Australia, 2016. DOI: 10.1109/powercon.2016.7753864.

18. Bukaros A. Ju., Onishhenko O. A. Modernizacija upravljaemyh privodov germetichnyh kompressorov, Elektrotehnichni ta komp'juterni sistemi, 2010, No. 01(77), pp. 58-63.

Received 01.10.2018. Accepted 12.11.2018 
УДК 681.51

\section{МОДЕРНІЗАЦІ СПОСТЕРІГАЧА ЛЮЕНБЕРГЕРА ДЛЯ СИСТЕМИ КЕРУВАННЯ ЕЛЕКТРОПРИВОДОМ ГЕРМЕТИЧНОГО КОМПРЕСОРА}

Букарос А. Ю. - канд. техн. наук, доцент кафедри електромеханіки та мехатроніки Одеської національної академії харчових технологій, Одеса, Україна.

Онищенко О. А. - д-р техн. наук, професор кафедри технічної експлуатації флоту Національного університету «Одеська морська академія», Одеса, Україна.

Монтік П. М. - канд. техн. наук, професор, завідувач кафедри електромеханіки та мехатроніки Одеської національної академії харчових технологій, Одеса, Україна.

Малишев В. Л. - аспірант кафедри автоматизації виробничих процесів Одеської національної академії харчових технологій, Одеса, Україна.

Букарос В. М. - аспірант кафедри технічної експлуатації флоту Національного університету «Одеська морська академія», Одеса, Україна.

\section{АНОТАЦІЯ}

Актуальність. Проведений аналіз існуючих систем бездатчикового керування електроприводами герметичних компресорів. Визначені основні вимоги, що застосовуються до систем керування автоматизованих електроприводів герметичних компресорів малих холодильних установок. Запропонована топологія адаптивного спостерігача Люенбергера, що дозволяє в реальному часі проводити оцінку поточного значення частоти обертання і моменту на валу електродвигуна герметичного компресора.

Мета. Об'єктом дослідження є спостерігач координат в складі системи керування електроприводом герметичного компресора. Мета роботи - розробка математичної моделі спостерігача координат в складі системи керування електроприводом герметичного компресора.

Метод. На основі лінеаризованої моделі трифазного асинхронного двигуна синтезований спостерігач Люенбергера модальним методом з розподілом коренів характеристичного полінома за стандартною лінійною формою Бесселя.

Результати. Отриманий характеристичний поліном спостерігача і розраховані коефіцієнти матриці Люенбергера і середньогеометричний корінь характеристичного полінома. Для забезпечення необхідної точності запропонована структура спостерігача на основі повної математичної моделі трифазного асинхронного двигуна, виконаної в нерухомій системі координат. У середовищі моделювання Matlab/Simulimk побудована імітаційна модель спостерігача Люенбергера, що включає повну математичну модель електродвигуна герметичного компресора в нерухомій системі координат. Засобами імітаційного моделювання досліджена робота спроектованого спостерігача Люенбергера на прикладі модернізованого трифазного асинхронного двигуна герметичного компресора побутового холодильника.

Висновки. Підтверджена ефективність запропонованого способу ідентифікації частоти обертання і моменту опору електродвигуна компресора адаптивним спостерігачем на основі обчислення електромагнітного моменту двигуна по виміряним даним датчиків фазних напруг і струмів. Похибка досліджуваного спостерігача не перевищує $0,5 \%$ по частоті обертання $\mathrm{i}$ $10 \%$ по моменту опору. Отримана структура адаптивного спостерігача Люенбергера дозволяє будувати замкнуті системи керування автоматизованим електроприводом герметичного компресора малої холодильної установки.

КЛЮЧОВІ СЛОВА: спостерігач Люенбергера, електропривод, система керування, герметичний компресор, холодильна установка

\section{УДК 681.51}

\section{МОДЕРНИЗАЦИЯ НАБЛЮДАТЕЛЯ ЛЮЕНБЕРГЕРА ДЛЯ СИСТЕМЫ УПРАВЛЕНИЯ ЭЛЕКТРОПРИВОДОМ ГЕРМЕТИЧНОГО КОМПРЕССОРА}

Букарос А. Ю. - канд. техн. наук, доцент кафедры электромеханики и мехатроники Одесской национальной академии пищевых технологий. Одесса, Украина.

Онищенко О. А. - д-р техн. наук, профессор кафедры технической эксплуатации флота Национального университета «Одесская морская академия», Одесса, Украина.

Монтик П. Н. - канд. техн. наук, профессор, заведующий кафедры электромеханики и мехатроники Одесской национальной академии пищевых технологий, Одесса, Украина.

Малышев В. Л. - аспирант кафедры автоматизации производственных процессов Одесской национальной академии пищевых технологий, Одесса, Украина.

Букарос В. Н. - аспирант кафедры технической эксплуатации флота Национального университета «Одесская морская академия», Одесса, Украина.

\section{АННОТАЦИЯ}

Актуальность. Проведен анализ существующих систем бездатчикового управления электроприводами герметичных компрессоров. Определены основные требования, предъявляемые к системам управления автоматизированных электроприводов герметичных компрессоров малых холодильных установок. Предложена топология адаптивного наблюдателя Люенбергера, позволяющая в реальном времени проводить оценку текущего значения частоты вращения и момента на валу электродвигателя герметичного компрессора.

Цель. Объектом исследования является наблюдатель координат в составе системы управления электроприводом герметичного компрессора. Цель работы - разработка математической модели наблюдателя координат в составе системы управления электроприводом герметичного компрессора. 
Метод. На основе линеаризованной модели трехфазного асинхронного двигателя синтезирован наблюдатель Люенбергера модальным методом с распределением корней характеристического полинома по стандартной линейной форме Бесселя.

Результаты. Получен характеристический полином наблюдателя и рассчитаны коэффициенты матрицы Люенбергера и среднегеометрический корень характеристического полинома. Для обеспечения необходимой точности предложена структура наблюдателя на основе полной математической модели трехфазного асинхронного двигателя, выполненной в неподвижной системе координат. В среде моделирования Matlab/Simulimk построена имитационная модель наблюдателя Люенбергера, включающая полную математическую модель электродвигателя герметичного компрессора в неподвижной системе координат. Средствами имитационного моделирования исследована работа спроектированного наблюдателя Люенбергера на примере модернизированного трехфазного асинхронного двигателя герметичного компрессора бытового холодильника.

Выводы. Подтверждена эффективность предложенного способа идентификации частоты вращения и момента сопротивления электродвигателя компрессора адаптивным наблюдателем на основе вычисления электромагнитного момента двигателя по измеренным данным датчиков фазных напряжений и токов. Погрешность исследуемого наблюдателя не превышает 0,5\% по частоте вращения и 10\% по моменту сопротивления. Полученная структура адаптивного наблюдателя Люенбергера позволяет строить замкнутые системы управления автоматизированным электроприводом герметичного компрессора малой холодильной установки.

КЛЮЧЕВЫЕ СЛОВА: наблюдатель Люенбергера, электропривод, система управления, герметичный компрессор, холодильная установка.

\section{ЛІТЕРАТУРА / ЛИТЕРАТУРА}

1. Онищенко О. А. Научное обоснование и разработка автоматизированных систем управления холодильнокомпрессионными установками малой производительности : дис. ... д-ра техн. наук : 05.13.07 / Онищенко Олег Анатольевич. - Одесса, 2010. - 345 с.

2. Applications of variable speed drive (VSD) in electrical motors energy savings / [R. Saidur, S. Mekhilef, M. B. Ali et al.] // Renewable and Sustainable Energy Reviews. 2012. - Vol. 16, № 1. - P. 543-550. DOI: 10.1016/j.rser.2011.08.020

3. Li Yu. Variable Frequency Drive Applications in HVAC Systems / Yu. Li, M. Chomat // New Applications of Electric Drives. - London : IntechOpen, 2015. - Chapter 7. - P 167-185. DOI: 10.5772/61782.

4. Войтех В. А. Частотное регулирование скорости вращения асинхронних двигателей компрессоров бытовых холодильников / В. А. Войтех // Технічна електродинаміка. Темат. вип. "Проблеми сучасної електротехніки”. - 2004. - № 3. - С. 61-63.

5. Ledesma S. Analysis and modeling of a variable speed reciprocating compressor using ANN / S. Ledesma, J. M. Belman-Flores, J. M. Barroso-Maldonado // International Journal of Refrigeration. - 2015. - Vol. 59. - P. 190197. DOI: 10.1016/j.ijrefrig.2015.08.009.

6. Grech N. Experimental Investigation of Variable Speed Operation of Air Conditioning / N. Grech, M. Farrugia // Heat Transfer, Fluid Mechanics and Thermodynamics : Ninth International Conference, Malta, 16-18 July 2012 : proceedings. - Malta : 2012. - P. 1674-1682.

7. Marshall R. C. Optimization of Single-unit Compressed Air Systems / R. C. Marshall // Energy Engineering. - 2012. Vol. $109 . \quad-\quad$ P. 10-35. DOI: 10.1080/01998595.2012.1043657.

8. Design and implementation of a variable frequency drive for single-phase induction motor / [M. Naveenkumar, A. Munjal, S. Srinivasan et al.] // Electrical and Computer Engineering : First International WIE Conference, Dhaka, 19-20 December 2015 : proceeding. - Los Alamitos : IEEE, 2015. P. 239-242. DOI: 10.1109/wiecon-ece.2015.7443907.

9. Букарос А. Ю. Моделирование момента сопротивления однопоршневого компрессора судовой холодильной ус- тановки / А. Ю. Букарос, В. Н. Букарос, О. А. Онищенко // Технологический аудит и резервы производства. 2015. - № 4(1). - C. 46-51.

10. Boldea I. The Induction Machine Handbook. Electric Power Engineering Series / I. Boldea, S. A. Nasar. - Boca Raton : CRC Press, 2010. - 968 p.

11. Krause P. C. Analysis of electric machinery and drive systems / P. C. Krause, O. Wasynczuk, S. D. Sudhoff. - New York : Wiley-IEEE, 2013. - 680 p.

12. MRAS and Luenberger Observer Based Sensorless Indirect Vector Control of Induction Motors / [M. Mustapha, L. Sbita, B. H. Mouna et al.] // Asian Journal of Information Technology. - 2008. - Vol. 7. - P. 232-239.

13. Khan M. R. Model reference adaptive system with simple sensorless flux observer for induction motor drive / M. R. Khan, A. Iqbal // Power Electronics, Drives and Energy Systems : IEEE International Conference, Bengaluru, 16-19 December 2012 : proceeding. - Los Alamitos : IEEE, 2012. - P. 1-6. DOI: 10.1109/PEDES.2012.6484442.

14. Kubota H. DSP-based speed adaptive flux observer of induction motor / H. Kubota, K. Matsuse, T. Nakano // IEEE transactions on industry applications. - 1993. - Vol. 29. P. 344-348.

15. Corriou J.-P. Process control: Theory and applications: Second edition / J.-P. Corriou. - New York : Springer, 2018. 860 p. DOI: 10.1007/978-3-319-61143-3.

16. Галагуз Т. А. Порівняння результатів синтезу робастних систем управління 3 використанням спостерігача Калмана та спостерігача Люенбергера / T. А. Галагуз, О. О. Абрамович, М. М. Комнацька // Системи управління, навігації та зв’язку. - 2010. - № 2(14). - С. 75-82.

17. Ning C. Kalman filtering speed estimation of vector control for induction motor drive / C. Ning // Power System Technology : IEEE International Conference, Wollongong, 28 September- 1 October 2016 : proceeding. - Los Alamitos : IEEE, 2016. - $\quad$ P. 107-111. DOI: 10.1109/powercon.2016.7753864.

18. Букарос А. Ю. Модернизация управляемых приводов герметичных компрессоров / А. Ю. Букарос, О. А. Онищенко // Електротехнічні та комп'ютерні системи. 2010. - № 01(77). - С. 58-63. 